INTIQAD: JURNAL AGAMA DAN PENDIDIKAN ISLAM

ISSN 1979-9950 (print) || ISSN 2598-0033 (online), http://jurnal.umsu.ac.id/index.php/intiqad DOI: 10.30596/intiqad.v12i2.5586

Vol. 12, No. 2 (December 2020)

\title{
Prinsip Bimbingan dan Konseling Islami dalam Kegiatan Pembinaan Mental di Sekolah Polisi Negara Kepolisian Daerah Sumatera Utara
}

\author{
Siti Asiyah ${ }^{\text {* }}$, Saipul Achyar ${ }^{2}$, Abdurrahman $^{3}$ \\ Universitas Islam Negeri Sumatera Utara*1, 2, 3 \\ *1email: Sitibata71@gmail.com \\ ${ }^{2}$ email:saifulakhyarlbs@uinsu.ac.id \\ 3email: abdurrahman@uinsu.ac.id
}

\begin{abstract}
The research was backed by researchers ' interest to examine the guiding principles of guidance and counseling in North Sumatera regional Police School. This research aims to find out how the role of guidance and counseling in Mental development activities in North Sumatera regional Police School. Mental view of students who are studying police schools in North Sumatera regional Police School. The method used in this research is qualitative in the narrative approaches, That is, the research procedure that produces the detailed data of the written or oral words of the observed behaviour. The research of guidance and counseling principles in North Sumatera regional Police School: First, the role of caregiver in the motivation of the state Police school students by applying the principles in guidance and counseling, so it is achieved a good and mental healthy learning. This can be seen from the student's success to complete the learning process at the state Police School. Secondly, students ' mental assessment is reviewed from the issue that students have restrictions and obligations. This is included in the final aspect of this diploma in: Academic values, physical value and the most important mental value of personality are mental values of personality.
\end{abstract}

\section{Keywords: Principles, Guidance and Counseling, Mental Health.}

Artikel Info

Received:

20 October 2020

Revised:

02 November 2020

Accepted:

21 November 2020

Published:

03 December 2020

Abstrak

Karya ilmiah yang ditulis oleh peneliti ini, diawali oleh keinginan peneliti sendiri untuk meneliti bagaiman prinsip bimbingan Konseling di SPN atau Sekolah Polisi Negara Kepolisian Daerah Sumatera Utara. Penelitian ini bertujuan untuk mengetahui peran Bimbingan dan Konseling dalam 
kegiatan Pembinaan Mental di Sekolah Polisi Negara Kepolisian Daerah Sumatera Utara. Melihat mental siswa yang sedang menjelani sekolah polisi di Sekolah Polisi Negara Kepolisian Daerah Sumatera Utara. Adapun metode yang dipakai dalam penulisan penelitian ini adalah kualitatif dalam pendekatan naratif, untuk menghasilkan data dekriptif berupa kata-kata tertulis atau lisan dari perilaku yang diamati. Hasil penelitian dari prinsip bimbingan Konseling di Sekolah Polisi Negara Kepolisian Daerah Sumatera Utara yaitu: pertama, peran pengasuh dalam motivasi siswa Sekolah Polisi Negara dengan menerapkan prinsip-prinsip dalam bimbingan dan konseling Islami, sehingga tercapai belajar yang baik dan mental yang sehat. Perkara semacam ini bisa dilihat dari keberhasilan siswa tersebut untuk merampungkan proses belajarnya di SPN atau Sekolah Polisi Negara. Kedua, penilaian mental siswa ditinjau dari masalah yang melakukan siswa terdapat larangan dan kewajiban. Hal ini termasuk dalam aspek penialain akhir di ijazah yaitu: nilai akademik, nilai jasmani dan nilai mental kepribadian yang paling terpenting adalah nilai mental kepribadian.

\section{Kata Kunci: Prinsip, Bimbingan dan Konseling, Kesehatan Mental.}

\section{A. Pendahuluan}

Sekolah tempat konselor bekerja merupakan salah satu lahan bagi terselenggaranya layanan bimbingan konseling. Di sekolah banyak peserta didik yang memiliki karakteristik dan kebutuhan yang berbeda, maka perlu adanya konselor untuk memberi pendidikan.

Pendidikan merupakan upaya sadar dan terencana dalam proses pembimbingan dan pembelajaran bagi individu agar tumbuh berkembang menjadi manusia yang mandiri, bertanggungjawab, kreatif, berilmu, sehat dan berakhlak (berkarakter) mulia (Suryadi, 2013).

Pasal 39 UU No. 20 Tahun 2003 tentang Sisdiknas, yang menyatakan bahwa pendidik merupakan tenaga professional yang bertugas merencanakan dan melaksanakan proses 
INTIQAD: JURNAL AGAMA DAN PENDIDIKAN ISLAM

ISSN 1979-9950 (print) || ISSN 2598-0033 (online), http://jurnal.umsu.ac.id/index.php/intiqad

DOI: 10.30596/intiqad.v12i2.5586

Vol. 12, No. 2 (December 2020)

pembelajaran, menilai hasil

pembelajaran, melakukan pembimbingan

dan pelatihan, serta melakukan

penelitian dan pengabdian kepada masyarakat (Undang-Undang Sisdiknas, 2003).

Kegiatan bimbingan dan konseling merupakan kegiatan yang bersumber pada kehidupan manusia, kenyataan menunjukkan bahwa manusia dalam kehidupannya sering menghadapi bermacam persoalan, ada yang bisa diselesaikan sendiri dan ada yang membutuhkan bantuan orang lain.

Istilah bimbingan dan konseling sebagaimana dalam literature professional di Indonesia, merupakan terjemahan dari kata Guidance dan Counseling dalam bahasa Inggris, menurut pemerintah no 28/1990 tentang Pendidikam Dasar, pasal 25 ayat 1 . Bimbingan adalah bantuan yang diberikan kepada siswa dalam rangka upaya menemukan pribadi, mengenal lingkungan dan meremcanakan masa depan (Winkel dan Hastuti, 2012).

\section{B. Pembahasan}

\section{Prinsip Bimbingan Konseling}

\section{Islami di SPN POLDA SUMUT}

Hasil wawancara dengan Kepala Sekolah Menengah Atas (SMA) tentang Prinsip Bimbingan Konseling Islami dapat memotivasi Belajar Siswa diperoleh keterangan sebagai berikut:

Sekolah Polisi Negara (SPN) POLDA SUMUT telah melaksanakan program Bimbingan Koseling dalam Prinsip Bimbingan Konseling sesuai program dan prosedur yang berlaku. Seperti guru-guru BK yang diterima di Sekolah Polisi Negara (SPN) POLDA SUMUT ini kita ambil sesuai dengan ketetapan pemenrintah yaitu harus dengan kepropesionalitasan legalitas ilmu dengan jurusan mereka, guru BK harus tamatan program studi bimbingan dan konseling. Walaupun belum sesuai dengan apa yang di tetapkan dalam Undang-undang kita dengan 1 guru BK menangani 150 siswa, guru yang ditetapkan sebagai Konselor atau Guru BK adalah guru yang diberikan penugasan sesuai dengan kebijakan yang dilakukan oleh SPN POLDA SUMUT ini. Dengan adanya guru BK dapat memberikan satu solusi bagi siswa dalam memotivasi belajar, hal ini juga dibantu oleh wali kelas. Walaupun ada juga diantara siswa yang malas dalam belajar atau pintar tapi tidak dapat tersalurkan, jadi bukan seorang anak yang menjadi patokannya, dan bagi guru-guru terutama wali kelas dan guru bimbingan konseling dapat mengembangkan potensi siawa sesuai dengan potensinya (Wawancara dengan Aiptu Sumarno, 2020).

Berdasarkan wawancara dengan guru BK tentang susunan organisasi guru BK di Sekolah Polisi Negara (SPN) 
INTIQAD: JURNAL AGAMA DAN PENDIDIKAN ISLAM

ISSN 1979-9950 (print) || ISSN 2598-0033 (online), http://jurnal.umsu.ac.id/index.php/intiqad

DOI: 10.30596/intiqad.v12i2.5586

Vol. 12, No. 2 (December 2020)

POLDA SUMUT dapat dilihat dalam bagan berikut.

\section{Bagan I}

Struktur Organisasi Organisasi berdasarkan Peraturan Kapolri Nomor 14 Tahun 2018 tanggal 21 September 2018 tentang Susunan Organisasi dan Tata Kerja Kepolisian Daerah.

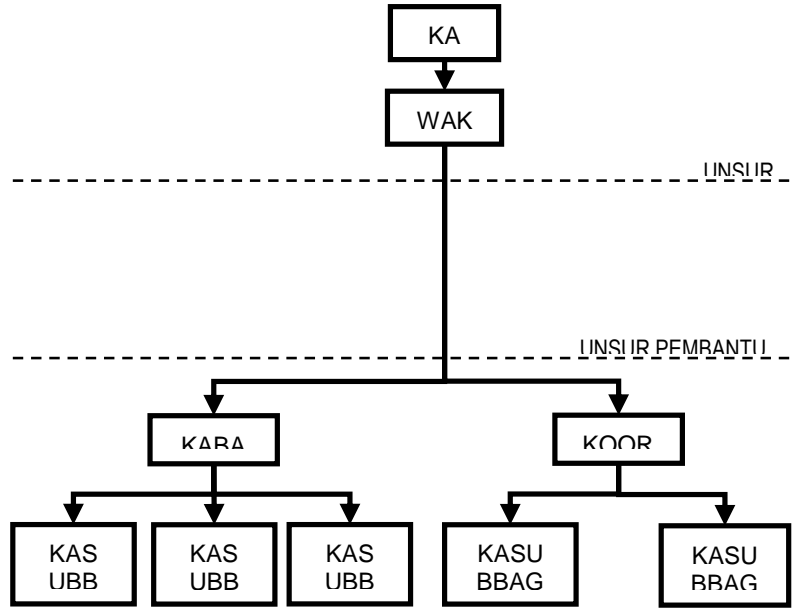

Hasil wawancara dengan kepala pengajaran (Koogadik), yang dilakukan dalam pengajaran selain Bimbingan dan Konseling yang dilaksanakan guru asuh setiap harinya di SPN POLDA SUMUT ini, juga ada kegiatan lainnya. Beliau mengatakan:

"Kegiatan Bimbingan Konseling seperti melaksanakan sholat berjamaah bagi yang menganut agama Islam dan bagi yang beragama Kristen melaksanakan Ibadah di hari Minggu, selesai melaksanakan Ibadah, ada bimbingan atau pengarahan seperti ceramah dan juga kata-kata motivasi lainnya" (wawancara dengan Kombes Pol Teguh Yuswardhie, 2020).

Mengenai penjelasan di atas kegiatan sholat berjama'ah ini adalah suatu program yang berawal dari inisiatif guru agama dan guru pengasuhan Bimbingan dan Konseling yang disampaikan kepada kepala SPN Polda Sumut. Hal ini mendapat sambutan yang positif untuk dilaksanakan sebagai tuntunan yang baik untuk siswa. Seperti yang telah dijelaskan oleh Ka. SPN Polda Sumut di atas, bahwa tujuan dilaksanakannya program sholat berjama'ah ini salah satunya adalah untuk meningkatkan rasa cinta ibadah bagi peserta didik.

Tujuan yang ingin dicapai dalam sebuah prinsip bimbingan konseling, diperlukan peran guru bimbingan dan konseling. Untuk mengetahui hal tersebut, dilakukan wawancara dengan Ka. SPN POLDA SUMUT mengenai motivasi belajar dalam proses Prinsip Bimbingan dan Konseling, di peroleh keterangan sebagai berikut.

Dalam Prinsip Bimbingan dan Konseling, sangat erat kaitannya dengan pembelajaran yang diadopsi oleh SPN POLDA SUMUT ini. Sebab kerja sama antara semua pihak harus benar berjalan dengan baik dan saling 
INTIQAD: JURNAL AGAMA DAN PENDIDIKAN ISLAM

ISSN 1979-9950 (print) || ISSN 2598-0033 (online), http://jurnal.umsu.ac.id/index.php/intiqad DOI: 10.30596/intiqad.v12i2.5586

Vol. 12, No. 2 (December 2020)

berkoordinasi. Kita juga menambahkan mata pelajaran Bimbingan Konseling SPN POLDA SUMUT kedalam kelas 4 Jam pelajaran pembentukan karakter kebhayangkaraan setiap minggu untuk membentuk karakter siswa agar menjadi lebih baik. Hal ini dilakukan untuk mensingkronkan laporan guru mata pelajaran kepada guru BK dalam membantu memecahkan masalah-masalah yang ada, serta membantu siswa dalam meningkatkan semangat belajar dan juga tidak terlepas pada Wakil Kepala SPN POLDA SUMUT Bidang Kesiswaan. Hal ini tidak di batasi dan tidak mengganggu jalannya proses pembelajaran didalam kelas selagi masih dalam keawajaran dan kebijkasanaan. Akan tetapi ini dapat membantu siswa agar mendapat nilai yang baik (wawancara dengan AKBP Henny Sorta Lubis, 2020).

Berdasarkan penjelasan yang dikemukan di atas dapat kita pahami bahwa Prinsip Bimbingan dan Konseling di SPN POLDA SUMUT memberikan dampak positif yang signifikan untuk siswa. Melalui pemberian Prinsip Bimbingan dan Konseling merupakan sarana untuk menunjang perkembangan optimal. Prinsip Bimbingan Konseling mengutamakan perkembangan kemampuan komunikasi dan sosialisasi. Kemampuan komunikasi dan sosialisasi sangat penting dimiliki oleh siswa agar siswa dapat bersikap aktif dan sehingga dapat berkomunikasi dan bersosialisasi dengan baik. Karena BK sudah mulai di singkronasikan dengan kurikulum yang ada di SPN POLDA SUMUT tersebut, sebab wali kelas, guru mata pelajaran dan juga guru BK saling berkoordinasi dan saling menaruh kepercayaan dalam membantu siswa menjadi lebih baik. Dengan demikian proses pelaksanaan kegiatan tersebut berjalan dengan baik dan sesui kebutuhan yang diperlukan.

Pelaksanaan Prinsip Bimbingan Konseling tersebut memberikan efek positif terhadapat siswa. Dengan saling bekerjasama antara wali kelas, guru matapelajaran dan guru BK, siswa merasa nyaman dan tenang sebab selalu diperhatikan. Tetapi perlu diperhatikan juga bahwa Wakil Kepala SPN POLDA SUMUT Bidang Kesiswaan punya tanggung jawab yang lebih besar, karena mengurusi dan menjadi jembatan penyediaan sarana dan fasilitas kegiatan dalam bimbingan.

Berdasarkan wawancara dengan guru BK tentang langkah-langkah dalam Prinsip Bimbingan Konseling Islami dalam menigkatkan motivasi belajar siswa sebagai berikut: 
INTIQAD: JURNAL AGAMA DAN PENDIDIKAN ISLAM

ISSN 1979-9950 (print) || ISSN 2598-0033 (online), http://jurnal.umsu.ac.id/index.php/intiqad

DOI: 10.30596/intiqad.v12i2.5586

Vol. 12, No. 2 (December 2020)

Langkah-langkah dalam Prinsip Bimbingan Konseling perlu di lakukan, 1) Menentukan tujuan yang akan dicapai, 2) Menganalisis tentang sumber-sumber dan kendala yang akan dihadapi, 3) Menganalisis tentang kebutuhan-kebutuhan yang diperlukan, 4) Menentukan tujuantujuan yang lebih spesifik dan dapat di ukur agar apa yang dinginkan tercapai, 5) Menentukan Prioritas apa yang harus di dulukan, 5) Menentukan strategi-strategi dan kegiatan-kegiatan yang berhubungan dengan tujuan-tujuan yang spesifik, 6) Mengadakan evaluasi terhadap perencanaan, dan yang terakhir, 7) Mengadakan beberapa perubahan-perubahan yang perlu untuk perbaikan dan meningkatkan motivasi belajar (wawancara dengan Aiptu Edi Suroso, 2020).

Berdasarkan urarian di atas dapat dipahami bahwa dalam langkah-langkah Prinsip Bimbingan Konseling sangat banyak yang perlu diperhatikan. Sebab, implikasinya langsung dirasakan siswa, maka perlu kehati-hatian dan keteletian dalam perencanaannya. Hal ini dilakukan agar guru BK dan siswa tidak ada yang merasa dirugikan dalam bentuk apapun.

Untuk mengetahui tentang Prinsip Bimbingan Konseling di SPN POLDA SUMUT, penulis melakukan wawancara dengan salah seorang siswa SPN tersebut. Berdasarkan hasil wawancara tentang Prinsip Bimbingan Konseling Islami dapat diperoleh keterangan sebagai berikut.

Menurut saya Prinsip Bimbingan dan Konseling di SPN POLDA SUMUT, selalu aktif dilaksanakan. Karena begitu banyak karakter siswa yang berbeda-beda sebab berasal dari berbagai daerah yang ada di Sumut, bahkah sampai di luar dari Sumatera Utara. Dan juga banyak dukungan yang didapat dari berbagai pihak. Kegiatan ini sangat membantu saya untuk berani mengutarakan pendapat, dengan perbedaan pendapat tersebut saya dan teman sekelas dapat menambah semangat belajar. Salah satu materi yang diberikan oleh guru untuk kegiatan Bimbingan dan Konseling ini, saya lebih semangat lagi belajar untuk memahami kesulitan-kesulitan yang saya hadapi salah satunya kesulitan atau permasalahan kedisplinan dan belajar, sehingga saya dapat memahami pelajaran serta dapat menyelesaikan suatu permasalahan yang ada (Wawancara dengan Valentino Purba, 2020).

Berdasarkan penjelasan di atas dapat dipahami bahwa Prinsip Bimbingan Konseling Islami di SPN POLDA SUMUT, telah terlaksana dengan maksimal. Hal ini dilakukan sebagai bukti adanya keseriusan pihak sekolah dalam penyelenggaraan bimbingan konseling khususnya Prinsip 
INTIQAD: JURNAL AGAMA DAN PENDIDIKAN ISLAM

ISSN 1979-9950 (print) || ISSN 2598-0033 (online), http://jurnal.umsu.ac.id/index.php/intiqad

DOI: 10.30596/intiqad.v12i2.5586

Vol. 12, No. 2 (December 2020)

Bimbingan Konseling SPN POLDA

SUMUT. Dalam hal ini sudah

seharusnya sekolah mengharapkan

kinerja maksimal dari guru bimbingan konseling.

Berdasarkan hasil observasi terhadap proses Prinsip Bimbingan Konseling di SPN POLDA SUMUT diperoleh data sebagai berikut.

\section{a. Mengidentifikasi}

Untuk melakukan Bimbingan terhadap siswa yang bermasalaah, guru Bimbingan dan Konseling terlebih dahulu mengidentifikasi materi pada kegiatan dalam pelaksanaan Prinsip Bimbingan Konseling.

\section{b. Diagnosa}

Diagnosa adalah Penentuan jenis masalah yang dihadapi siswa SPN POLDA SUMUT dengan cara memeriksa gejala atau apa yang terjadi dengan siswa tersebut. Berikutnya menentukan apa yang terjadi pada siswa. Setelah itu baru ditentukan persoalan yang dihadapi siswa.

\section{c. Progrnosis}

Prognosis adalah Ramalan tentang peristiwa yang akan terjadi dalam penyelesain masalah siswa. Secara konseling dapat di artikan bahwa prognosis merupakan aktifitas penyusunan rencana atau program yang diharapkan dapat mmbantu mengatasi masalah siswa SPN POLDA SUMUT tersebut.

\section{d. Terapi atau pemberian bantuan}

Terapi merupakan usaha untuk memberikan penanganan kepada siswa agar dapat menjadi lebih baik lagi ataumendapatkan motivasi yang lebih untuk dirinya sendiri.

\section{e. Tindak lanjut}

Selanjutnya adalah melakukan tindak lanjut sejauh mana keberhasilan rencana dan program yang telah dibuat dan melakukan terapi atau memberikan bantuan kepada siswa tersbut.

Dari uraian observasi di atas dapat diambil kesimpulan bahwa peran guru Bimbingan dan Konseling dalam melaksanakan Bimbingan dan Konseling adalah upaya dalam memberikan bimbingan dan arahan kepada siswa yang mengalami kesulihan di Sekolah SPN POLDA SUMUT melalui prosedur kelas. Proses pelaksanaan kegiatan diarahkan untuk membantu siswa dalam memahami dirinya sendiri, meningkatan motivasi belajarnya, mengutarakan pendapat sendiri, saling menghargai pendapat yang ada pada diri siswa yang diarahkan untuk memliki kemampuan 
yang lebih pada siswa tersebut, sampai fokus ke penyelesaian masalah belajar di Sekolah yang diselesaikan secara bersama.

Berdasarkan hasil wawancara peneliti dengan salah satu siswa mengenai minat mengikuti kegiatan Bimbingan dan Konseling yang dilaksanakan setiap minggunya, siswa tersebut mengatakan:

Dalam hal ini minat siswa atau teman sekelas untuk mengikuti pelaksanaan kegiatan Bimbingan Konseling ada beberapa faktor, yaitu: faktor siswa yang membutuhkan suatu Bimbingan dan Konseling, faktor siswa merasa tertarik mengikuti Bimbingan dan Konseling dikarenakan ada motivasi di dalam pengajaran, faktor siswa akrab dengan guru BK atau pengasuh siswa, faktor semangat siswa untuk mengeluarkan pendapat, faktor siswa yang saling terbuka dalam Bimbingan Konseling, faktor siswa atau anggota yang saling bertoleransi, dan faktor guru BK yang dapat mengelola di dalam Prinsip Bimbingan Konseling Islami (Wawancara dengan Nauli RS, 2020).

Mengenai penjelasan dari salah satu siswa SPN POLDA SUMUT di atas bahwa ada beberapa faktor minat siswa mengikuti Bimbingan Konseling. Dari ketujuh faktor tersebut peneliti melihat dan mengamati langsung menjadi faktor utama untuk minat siswa mengikuti Bimbingan Konseling ini adalah faktor guru BK yang dapat mengelola Bimbingan Konseling dengan baik. Dalam hal ini guru BK sebagai pemimpin kelas melakukan pendekatan salah satunya adalah Human Relationship.

Untuk saat ini ada beberapa program kerja yang dimiliki oleh sekolah ini yang terbagi menjadi dua bagian program, antara lain:

\section{1) Program Unggulan}

a) Mengembangkan sikap dan kompetensi keagamaan

b) Mengembangkan kemampuan bahasa dan teknologi informasi.

\section{2) Program sarana prioritas}

Menyediakan dan melengkapai berbagai sarana yang dibutuhkan, dan yang sesuai dengan pendidikan kepolisian di SPN POLDA SUMUT.

\section{Prinsip Bimbingan Kenseling di SPN POLDA SUMUT}

Prinsip Bimbingan Konseling yang merupakan bagian dari kegiatan konseling. Prinsip yang melihat dinamika kelas yang terjadi selama kegiatan bimbingan berlangsung. Pada awal kegiatan dilakukan dinamika kelas 
ISSN 1979-9950 (print) || ISSN 2598-0033 (online), http://jurnal.umsu.ac.id/index.php/intiqad

DOI: 10.30596/intiqad.v12i2.5586

Vol. 12, No. 2 (December 2020)

belum sepenuhnya sesuai dengan harapan. Hal ini dikarenakan siswa dari latar suku dan adat yang berbeda, dengan dilakukan kegiatan Bimbingan dan Konseling maka terlihat ada perubahan terhadap siswa. Dinamika kelas secara perlahan terjadi pada tiap kelas yang dibentuk, mulai dari kesiplinan, keberanian mengungkapkan pendapat saat bimbingan sedang berlangsung hingga saling bertukar pendapat dengan anggota kelas lainnya.

Berdasarkan wawancara dengan guru BK (pengasuh siswa) tentang pelaksanaan Prinsip Bimbingan Konseling di SPN POLDA SUMUT Hinai Kabupaten Langkat dapat diperoleh keterangan sebagai berikut.

Prinsip Bimbingan Konseling Islami di SPN POLDA SUMUT, adalah sebagai media pemberian informasi yang ditujukan untuk mencegah timbulnya masalah belajar dan kedispilan pada siswa sehingga melahirkan siswa yang bermental sehat dan meningkatkan potensi kognitif yang dimiliki siswa dalam lingkungan SPN POLDA SUMUT maupun di luar SPN ini (Wawancara dengan Aiptu Edi Suroso, 2020).

Mengenai penjalasan di atas dapat dipahami bahwa pelaksanaan dari Prinsip Bimbingan Konseling di SPN POLDA SUMUT sebagai media informasi menghambat permasalahan yang akan terjadi pada siswa sehingga siswa yang dapat memahami materi yang diberikan pada kegiatan tersebut, dapat meningkatkan potensinya bukan hanya di lingkungan SPN saja melainkan selesai dari SPN ini dan ditugaskan. Secara umum, Prinsip Bimbingan Konseling yang dilaksanakan di SPN POLDA SUMUT ini sangat membantu dalam berinteraksi dimanapun, dan dapat diaplikasikan di luar atau sudah ditugaskan.

Berdasarkan wawancara dengan guru BK tentang perencanan dalam melaksanaan Prinsip dan Bimbingan Konseling di SPN POLDA SUMUT adalah sebagai berikut.

Di dalam melaksanakan Prinsip Bimbingan Konseling diperlukan perencanan yang matang. Karena apabila tidak perencanaan sebelum tindakan yang dilakukan maka hasilnya akan tidak maksimal. Diantara perencanaan Prinsip Bimbingan Konseling meliputi, 1) membuat materi, 2) mengatur waktu kegiatan, 3) menyesuaikan bidang 4) menetapkan jenis, dan 5) mengetahui fungsi bimbingan dan konseling (Wawncara denan Aiptu Edi Suroso, 2020).

Berdasarkan penjelasan di atas dapat difahami bahwa perencanaan pelaksanaan dari Bimbingan Konseling 
INTIQAD: JURNAL AGAMA DAN PENDIDIKAN ISLAM

ISSN 1979-9950 (print) || ISSN 2598-0033 (online), http://jurnal.umsu.ac.id/index.php/intiqad

DOI: 10.30596/intiqad.v12i2.5586

Vol. 12, No. 2 (December 2020)

sudah berjalan dengan baik sesuai Negara (SPN) POLDA SUMUT sebagai dengan tahapan perencanan Prinsip kegiatan tersebut. Tujuan dari perencanaan pelaksanaan dari kegiatan ini adalah anggota kelas dapat memenuhi rangkaian kegiatan terlaksana dengan baik.

\section{Langkah-langkah dalam Prinsip}

\section{Bimbingan Konseling Islami}

Berdasarkan wawancara dengan guru BK tentang pelaksanaan proses Prinsip Bimbingan Konseling di SPN POLDA SUMUT dapat diperoleh keterangan sebagai berikut:

Dalam pelaksanaan proses Prinsip Bimbingan Konseling SPN POLDA SUMUT terdapat beberapa tahapan yang dilaksanakan. Secara umum proses kegiatan dibagi atas empat tahapan: 1) Tahap pembentukan, 2) Tahap peralihan, 3) Tahap pelaksanaan kegiatan, dan 4) Tahap pengakhiran (Ibid).

Berdasarkan penjelasan yang dikemukakan di atas dapat difahami bahwa proses dalam pelaksananan Prinsip Bimbingan Konseling terdiri atas empat tahap.

Berdasarkan hasil observasi terhadap tahapan proses Prinsip Bimbingan Konseling di Sekolah Polisi

berikut (hasil Observasi, 2020):

\section{a. Tahap Pembentukan}

Tahap pembentukan yaitu tahapan untuk membentuk kerumunan sejumlah individu menjadi satu kelas yang siap mengembangkan dinamika kelas dalam mencapai tujuan bersama. Pemahaman ini memungkinkan anggota untuk berperan secara aktif dalam Bimbingan Konseling dan selanjutnya dapat menumbuhkan minat untuk mengikuti Bimbingan Konseling. Tahap ini juga bertujuan untuk menumbuhkan suasana saling mengenal, saling percaya, saling menerima dan membantu antar anggota kelas. Adapun proses pelaksanaan Prinsip Bimbingan Konseling dalam tahap pembentukan tersebut sebagai berikut:

1) Menumbuhkan suasana untuk bisa saling mengenal, saling percaya, saling menerima dan membantu antar anggota kelas. Menyiapkan anggota kelas untuk mengikuti Prinsip dengan menanyakan kabar mereka pada hari ini. Kegiatan yang dilakukan dalam tahap ini adalah pengungkapan dan tujuan dari kelas dalam rangka Prinsip bimbingan dan konseling. Dengan demikian, tahap awal ini 
INTIQAD: JURNAL AGAMA DAN PENDIDIKAN ISLAM

ISSN 1979-9950 (print) || ISSN 2598-0033 (online), http://jurnal.umsu.ac.id/index.php/intiqad

DOI: 10.30596/intiqad.v12i2.5586

Vol. 12, No. 2 (December 2020)

telah terlaksana dengan baik, dengan kunci saling mengenal dan pengungkapan diri dari anggota kelas.

2) Mengungkapkan pengertian dan tujuan kegiatan. Hubungan antara guru BK dan siswa yang melaksanakan Prinsip Bimbingan Konseling tersebut sangat erat. Oleh sebab itu peran guru BK dalam membantu memperjelas masalah yang dihadapi oleh siswa sangat penting. Demikian pula apabila konseli/siswa tidak memhamai akan potensi yang dimilikinya, maka tugas dari konselor/guru bimbingan konseling yang akan membantu dan mengembangkan potensi yang ada pada siswa tersebut, memperjelas potensi siswa selama di SPN POLDA SUMUT, dan membantu pembentukan karakter agar tercipta mental yang sehat.

3) Penumbuhan sikap saling mempercayai dan saling menerima. Sesuai dengan materi kegiatan yang telah diberikan oleh guru $\mathrm{BK}$, bisa memelihara kesepakatan dan menumbuhkembangkan kesadaran dan rasa memiliki terhadap apa yang telah disepakati di dalam kelas tersebut. Berdiskusi adalah cara yang tepat untuk saling menerima teman sekelas. Prinsip yang diterapkan dalam hal saling menerima ini sederhana, jika ingin diterima maka perlu menerima orang lain tanpa mencoba untuk mengubah mereka sesuai pandangan anda.

4) Memulai pembahasan tentang tingkah laku dan suasana perasaan dalam kelas. Suatu kelas yang terdiri dari dua orang atau lebih yang berinteraksi, berkomunikasi, dan mempengaruhi satu sama lain selama beberapa waktu. Mengenai hal ini yang mengikuti kegiatan Prinsip Bimbingan Konseling di SPN POLDA SUMUT, ini diberikan dengan dua alasan umum mengapa orang bergabung di suatu kelas, yaitu untuk mencapai tujuan dan memuaskan kebutuhan sesuai yang di harapkan oleh Sekolah. Pada umumnya perasaan berkaitan dengan persepsi, dan merupakan reaksi stimulus yang mengenainya, bersifat subjektif hingga lebih subjektif apabila dibandingkan dengan peristiwa psikis yang lain.

\section{b. Tahap Peralihan}

Tahap yang kedua adalah tahap peralihan yang disebut sebagai tahap 
INTIQAD: JURNAL AGAMA DAN PENDIDIKAN ISLAM

ISSN 1979-9950 (print) || ISSN 2598-0033 (online), http://jurnal.umsu.ac.id/index.php/intiqad

DOI: 10.30596/intiqad.v12i2.5586

Vol. 12, No. 2 (December 2020)

transisi, yaitu setelah pembentukan dan sebelum kerja (pembelajaran). Pada tahap ini pemimpin kelas menjelaskan peranan para anggota kelas dalam "kelas bebas" ataupun kelas tugas", kemudian pemimpin kelas menawarkan apakah anggota kelas sudah siap untuk memulai kegiatan selanjutnya. Tugas pemimpin kelas dalam tahap peralihan ini adalah membantu para anggota untuk mengenali dan mengatasi berbagai macam hambatan, rasa gelisah, rasa enggan. Setelah ini pemimpin kelas mengajak anggota kelas yang telah siap untuk segera memasuki tahap kegiatan.

Adapun yang dilaksanakan dalam tahap peralihan (transisi) ini yaitu:

1) Menjelaskan kegiatan yang akan ditempuh pada tahap berikutnya, pada tahap ini peran pemimpin kelas sangat diperlukan untuk memberikan pemahaman mengenai materi yang disampaikan oleh guru BK sebagai bahan untuk diskusi dalam Prinsip Bimbingan Konseling. Jika sifat yang dilihatkan oleh anggota kelas bersemangat dalam menerima materi maka tahap selanjutnya akan lebih baik lagi di laksanakan.

2) Menawarkan atau mengamati apakah para anggota sudah siap menjalani kegiatan pada tahap selanjutnya. Pada tahap ini anggota kelas sudah dapat memahami maksud dari tahap sebelumnya, dan melihat sudah sejauh mana semangat anggota kelas dalam menerima materi.

3) Membahas suasana yang terjadi di sekolah. Pemimpin kelas mengkondisikan anggota kelasnya sesuai dengan suasana yang terjadi.

4) Meningkatkan kemampuan siswa. Tahap selanjutnya, pemimpin kelas harus mengetahui kemampuan rekan kelasnya.

5) Bila perlu kembali kepada beberapa aspek tahap. Ada beberapa hal penting yang harus diperhatikan oleh seorang pemimpin, yaitu:

a) Menerima suasa yang ada secara sabar dan terbuka

b) Tidak mempergunakan cara-cara yang bersifat langsung atau mengambil alih kekuasaannya

c) Mendorong dibahasnya suasana perasaan

d) Membuka diri, sebagai contoh dan penuh empati.

\section{c. Tahap Kegiatan}

Tahap ini merupakan inti dari kegiatan kelas, maka aspek-aspek yang menjadi isi dan pengiringnya cukup 
banyak. Aspek tersebut perlu mendapat perhatian yang seksama dari pemimpin kelas. Ada beberapa yang harus dilakukan oleh pemimpin dalam tahap ini, yaitu sebagai pengatur proses kegiatan yang sabar dan terbuka, aktif, akan tetapi tidak banyak bicara, dan memberikan dorongan dan penguatan serta penuh empati. Tahap ini ada berbagai kegiatan yang dilaksanakan, yaitu:

1) Pada tahap ini, peran anggota kelas bebas untuk mengemukakan pendapat mengenai materi yang disampaikan oleh guru bimbingan dan konseling.

2) Menetapkan topik yang akan dibahas terlebih dahulu. Topik bahasan dibahas pada pelajaran berlangsung, anggota kelas saling mendiskusikannya.

3) Anggota membahas topik secara mendalam dan tuntas. Lanjutan dari tahap sebelumnya. Tahap ini merupakan pendalaman materi agar sesuai dengan harapan untuk mencapai tujuan kegiatan.

4) Kegiatan selingan. Tahap kegiatan selingan ini, maksudnya sesuatu untuk menyelingi atau menyelang perbuatan (intermezzo), bisa juga untuk melakukan hiburan-hiburan dan diberikan pada waktu berdiskusi antar sesama anggota kelas.

\section{d. Tahap Pengakhiran}

Pada tahap pengakhiran Bimbingan Konseling, pokok perhatian utama bukanlah pada berapa kali kelas itu harus bertemu, tetapi pada hasil yang telah dicapai seyogyanya mendorong kelas itu harus melakukan kegiatan sehingga tujuan bersama tercapai secara penuh. Dalam hal ini ada kelas yang menetapkan sendiri kapan kelas itu akan berhenti melakukan kegiatan, dan kemudian bertemu kembali untuk melakukan kegiatan. Ada beberapa hal yang dilakukan pada tahap ini, yaitu:

1) Pemimpin kelas mengemukakan bahwa kegiatan akan segera diakhiri

2) Pemimpin dan anggota kelas mengemukakan kesan dan hasilhasil kegiatan

3) Membahas kegiatan lanjutan

4) Mengemukakan pesan dan harapan.

Setelah kegiatan kelas pada tahap pengakhiran, kegiatan kelas hendaknya dipusatkan pada pembahasan dan penjelajahan tentang apakah para anggota kelas mampu menerapkan halhal yang mereka pelajari (dalam suasana 
kelas), pada kehidupan nyata mereka sehari-hari.

Berdasarkan hasil wawancara peneliti dengan guru BK berkenaan dengan kesukaran dalam Prinsip Bimbingan Konseling Islami di SPN POLDA SUMUT, beliau mengatakan:

Dalam melaksanakan Prinsip Bimbingan Konseling di SPN POLDA SUMUT ini, tentu saja ditemui kesukaran, namun tidak semua kesukaran tersebut berasal dari ketidak kesempurnaan pengkordiniran yang dilakukan guru bimbingan dan konseling, tetapi ada juga berasal dari faktor diri individu siswa yang digunakan dalam proses Bimbingan Konseling (Observasi, 2020.

Oleh sebab itu, guru BK selalu sukar untuk mengkordinir siswa dalam hal sarana yang ada di dalam kelas, sehingga waktu yang diberikan dalam Prinsip Bimbingan Konseling Islami berkurang.

\section{Komponen dalam Prinsip}

\section{Bimbingan Konseling Islami}

Berdasarkan hasil observasi di lapangan dan wawancara yang dilakukan dengan guru BK di SPN POLDA SUMUT ini, diperoleh keterangan bahwa:

Komponen dalam pelaksanaan kegiatan Bimbingan Konseling yang dilaksanakan di Sekolah Polisi Negara (SPN) POLDA SUMUT Hinai Kabupaten Langkat ini adalah pemimpin kelas dan anggota kelasnya (Wawancara dengan Suroso, 2020).

Sesuai data yang diperoleh bahwa pemimpin kelas memiliki peran penting dalam rangka membawa para anggotanya menuju suasana yang mendukung untuk tercapainya tujuan Bimbingan Konseling tersebut.

\section{Materi dalam Prinsip Bimbingan}

\section{Konseling Islami}

Berdasarkan wawancara dengan

Guru bimbingan konseling tentang Prinsip Bimbingan Konseling Islami di Sekolah Polisi Negara (SPN) POLDA SUMUT sebagai berikut:

a. Pertemuan pertama, yaitu Prinsip Bimbingan Konseling dengan materi pemahaman diri sendiri.

b. Pertemuan kedua, yaitu Prinsip Bimbingan Konseling dengan materi motivasi.

c. Pertemuan ketiga, yaitu Prinsip Bimbingan Konseling dengan materi menghargai pendapat orang lain.

d. Pertemuan keempat, yaitu Prinsip Bimbingan Konseling dengan materi berpikir positif. 
ISSN 1979-9950 (print) || ISSN 2598-0033 (online), http://jurnal.umsu.ac.id/index.php/intiqad

DOI: 10.30596/intiqad.v12i2.5586

Vol. 12, No. 2 (December 2020)

e. Pertemuan kelima, yaitu Prinsip Bimbingan Konseling dengan materi fokus pada tujuan (Wawancara, Edi Suroso, 2020).

\section{Evaluasi}

Evaluasi adalah upaya, tindakan atau proses untuk menentukan derajat kualitas kemajuan kegiatan yang berkaitan dengan pelaksanaan program kegiatan boimbingan kelas. Tujuan dari evaluasi ini adalah untuk mengetahui ketercapaian program seseuai dengan jabaran atau butir-butir program kegiatan Prinsip Bimbingan Konseling dan untuk mengetahui ketercapaian Prinsip Bimbingan Konseling Islami yang di laksanakan oleh guru BK sebagai pemimpin kelas dan siswa di SPN POLDA SUMUT.

Berdasarkan wawancara dengan guru BK tentang tindak lanjut setelah pelaksanaan kegiatan Bimbingan Konseling dilakukan adalah sebagai berikut.

Setelah semua perencanaan dan pelaksanan dari Prinsip Bimbingan Konseling dilaksanakan, dan hasil dari Prinsip Bimbingan Konseling di sekolah SPN adalah siswa menjadi aktif dan bagus nilai pada pelajaran umum. selanjutnya adalah menyusun tindak lanjut kedepannya. Setelah Prinsip
Bimbingan Konseling di SPN POLDA SUMUT terlaksana dengan baik.

Berdasarkan wawancara di atas dapat dipahami bahwa, setelah seluruh perencanaan dan Prinsip konseling Islam individu telah dilaksanakan, selanjutnya adalah tindak lanjut dari pelaksanaan tersebut. Mengukur sudah sejauh mana Prinsip konseling Islam dilakukan dan tingkat keberhasilannya harus dilihat. Hal ini dilakukan agar kedepannya Prinsip konseling Islam tepat sasaran dan semakin berhasil di setiap program dan Prinsip konseling Islam. Kemudian yang terakhir adalah membuat laporan untuk dicatatkan.

Sebagaimana yang telah ditegaskan dalam teknik analisis, penelitian menggunakan analisis kualitatif (pemaparan) dari data yang didapatkan baik melalui observasi dan, dokumentasi dan interview dari pihak yang mengetahui tentang data yang dibututuhkan dan selanjutnya dari hasil tersebut dikaitkan dengan teori yang ada, maka dapatlah dilakukan pembahasan pada hasil penelitian.

Berdasarkan hasil observasi peneliti mengenai hasil yang didapat setelah diadakannya kegiatan bimbingan 
dan kelas di SPN POLDA SUMUT. Hasil yang didapat pada Prinsip Bimbingan Konseling Islami dilihat dari respon siswa, keaktifan siswa, dan perubahan siswa belajar, khususnya siswa. Berdasarkan observasi di lapangan dalam pelaksanaan Prinsip Bimbingan Konseling mengenai evaluasi dari Prinsip Bibingan Konseling Islami tersebut adalah sebagai berikut:

\section{a. Respon Siswa}

Ketika Prinsip Bimbingan

Konseling Islami siswa cukup baik hal itu terlihat dari sikap siswa yang mau memberikan jawaban ketika guru BK bertanya dan ketika Prinsip Bimbingan Konseling Islami siswa memiliki respon yang cukup aktif dalam mengikuti kegiatan proses belajar mengajar yang sedang berlangsung. Pada awalnya siswa sedikit malu untuk mengungkapkan atau menyampaikan pendapat yang ingin mereka kemukakan karena takut jika jawaban mereka salah. Kemudian guru BK dan guru mata pelajaran memberingan dorongan kepada siswa bahwasanya tidak ada jawaban salah ataupun benar. Setelah itu, siswa mulai aktif merespon apa yang ditanyakan oleh rekan kelas yang lain.

\section{b. Keaktifan Siswa}

Seperti yang telah dikemukakan di atas bahwa siswa aktif dalam mengikuti kegiatan dalam Bimbingan Konseling. Sebab ada timbal balik yang dilakukan oleh siswa, ketika siswa merasa tidak tahu dengan apa yang telah diungkapkan oleh guru BK, guru mata pelajaran dan siswa pun dapat di lihat juga dari gestur tubuh yang terlihat sangat antusias dalam belajar di kelas.

\section{c. Perubahan Siswa}

Setelah guru BK melakukan Bimbingan Konseling, siswa mengambil perubahan dalam hal berkomunikasi yakni dalam berpendapat, siswa mulai memberikan kontibusinya yang baik dalam tahap awal. Guru BK mengira para siswa akan sulit dalam belajar, tetapi dalam pelaksanaannya siswa memberikan pendapat memahami materi yang diberikan.

\section{d. Tahap-tahap dan Teknik yang Digunakan}

Teknik yang digunakan adalah diskusi kelas dan home room. Home room adalah suatu teknik Prinsip Bimbingan Konseling yang dilakukan dengan cara menciptakan situasi yang bersifat kekeluargaan (suasana seperti di rumah). 
INTIQAD: JURNAL AGAMA DAN PENDIDIKAN ISLAM

ISSN 1979-9950 (print) || ISSN 2598-0033 (online), http://jurnal.umsu.ac.id/index.php/intiqad

DOI: 10.30596/intiqad.v12i2.5586

Vol. 12, No. 2 (December 2020)

Berdasarkan hasil ovservasi di atas dapat diambil kesimpulan bahwa pelaksanaan tahapan proses Prinsip Bimbingan Konseling Islami di SPN POLDA SUMUT Adapun usaha bimbingan konseling Islami dalam meningkatkan motivasi belajar siswa di SPN POLDA SUMUT dilakukan dengan cara menerapkan konsep Islami yaitu mengajak seluruh siswa untuk melakukan ibadah sholat berjamaah dalam hal ini melakukan sholat dhuha dan sholat dzhuhur, melakukan ritual berdoa sebelum melakukan aktivitas akademis di sekolah dan dikelas. Menurut informasi yang diberikan guru Bimbingan Konseling (BK) bahwa sejauh ini program bimbingan konseling yang dilakukan di sekolah SPN Hinai khususnya pada semua siswa sudah sangat efektif dalam rangka meningkatkan motivasi belajar siswa.

\section{Temuan Penelitian}

Sebagaimana yang telah ditegaskan dalam teknik analisis, penelitian ini menggunakan analisis kualitatif (pemaparan) dari data yang didapatkan baik melalui observasi, dokumentasi dan interview dari pihak yang mengetahui tentang data yang dibutuhkan dan selanjutnya dari hasil tersebut dikaitkan dengan teori yang ada, maka peneliti memaparkan pembahasan pada hasil penelitian tersebut.

Berdasarkan hasil ovservasi diatas dapat diambil kesimpulan bahwa pelaksanaan tahapan proses Prinsip Bimbingan Konseling Islami di SPN POLDA SUMUT. Adapun usaha bimbingan konseling Islami dalam meningkatkan motivasi belajar siswa SPN POLDA SUMUT dilakukan dengan cara menerapkan konsep Islami yaitu mengajak seluruh siswa untuk melakukan ibadah sholat berjamaah dalam hal ini melakukan sholat dhuha dan sholat dzhuhur, melakukan ritual berdoa sebelum melakukan aktivitas akademis di sekolah dan dikelas. Menurut informasi yang diberikan guru BK bahwa sejauh ini program bimbingan konseling yang dilakukan di sekolah SPN Hinai khususnya pada siswa sudah sangat efektif dalam rangka meningkatkan motivasi belajar siswa.

Proses pelaksanaan program bimbingan konseling dilakukan oleh guru Bimbingan Konseling yang bernama Aiptu Edi Sumorno, dengan latar belakang pendidikan kepolisian, bukan berlatar belakang pendidikan 
INTIQAD: JURNAL AGAMA DAN PENDIDIKAN ISLAM

ISSN 1979-9950 (print) || ISSN 2598-0033 (online), http://jurnal.umsu.ac.id/index.php/intiqad

DOI: 10.30596/intiqad.v12i2.5586

Vol. 12, No. 2 (December 2020)

konseling, sehingga materi dan metode pembelajaran yang diberikan kepada siswa SPN Hinai Kabupaten Langkat oleh guru tersebut hanya diperoleh dari buku-buku paket dan dari internet, yang dirangkumnya sendiri (Inisiatif Sendiri) dan dari proses pelatihan maupun workshop yang diikuti guru tersebut di luar dari sekolah. Meskipun demikian tidak mengurangi kemampuan dan kualitas guru tersebut untuk menerapkan teori dan metode pembelajaran bimbingan konseling terhadap siswa SPN Hinai Kabupaten Langkat. Hal ini dapat dilihat dari keberhasilan siswa tersebut untuk menyelesaikan proses belajarnya di sekolah SPN Hinai Kabupaten Langkat.

Pilihan terhadap siswa di sekolah SPN ini, awalnya untuk membantu siswa tersebut untuk menentukan Kepribadian serta bermental yang kuat, tetapi ternyata di SPN Hinai Kabupaten Langkat, sudah menentukan pilihannya dengan tidak melanggar aturan yang ditetapkan di SPN Polda Sumut. Sehingga ketika selesai dari pembelajaran di SPN jika siswa mengikuti dengan aturan yang benar maka akan terlahir siswa bermental sehat dan akan baik dimana siswa ditugaskan.
Strategi yang digunakan guru bimbingan konseling untuk menerapkan materi konseling ke siswa dengan cara individu (perorangan), dengan alasan agar guru bimbingan konseling tersebut memperoleh data dan informasi yang lebih akurat dan terperinci.

Evaluasi secara khusus dilakukan pada masa tahap akhir pembelajaran dengan cara melihat hasil belajar siswa. Adapun faktor penghambat dalam melaksanakan usaha bimbingan konseling Islami dalam meningkatkan motivasi belajar siswa di SPN POLDA SUMUT adalah:

a. Latar belakang Guru Bimbingan Konseling yang bukan dari Pendidikan Bimbingan Konseling

b. Orangtua yang tidak terbuka atas masalah siswa yang membutuhkan bimbingan konseling

c. Metode dan materi pembelajaran bimbingan konseling Islami yang tidak secara rinci (tidak memiliki standar khusus sebagai tolak ukur keberhasilan suatu teori).

d. Sarana dan Prasarana yang kurang mendukung. 


\section{Simpulan}

Berdasarkan hasil penelitian di atas maka penelitian ini dapat disimpulkan sebagai berikut.

1. Adapun peran Bimbingan dan Konseling dalam kegiatan Pembinaan Mental di Sekolah Polisi Negara Kepolisian Daerah Sumatera Utara dilakukan dengan cara pembinaan fisik. Hal ini sangat tidak nyaman jika tidak diterima dengan sehat dari mental siswa. Dengan bantuan piket untuk dapat mempermudah siswa untuk tepat waktu. Dan pengasuhan adalah konselor pada siswa. Dengan waktu 7 bulan harus bisa menyelesaikan 25 mata pelajaran dengan alokasi waktu 1400 jam pelajaran. Jadi pengasuh harus bisa menjadi pendidik di kelas juga. Pengasuhan sangat berperan penting dalam melaksanakan bimbingan konseling pada siswa. Karena pengasuhan merupakan bapak asuh dari sisiwa-siswanya. Di sekolah polisi negara ada mata pelajaran karakter kebayangkaraan 60 jp, ada mata pelajaran tentang Prinsip kebayangkaraan dan kepribadin bangsa (revolusi mental
20 jp. Dan yang terakhir pemdidikan buadaya anti korupsi (PBAK). Sesuai dengan 3 tahap: tahap pertama 2 bulan, tahap ke dua 4 setengah dan tahap ketiga sampai pada setenagh bulan. Satiaji (dokrin) atau memotivasi pada saat malam hari. Pagi 7-8 dapat pengasuh dapat memberikan motivasi, perangkat pengasuh dapat memengang 25 siswa. Sehingga dengan adanya pengasuh yang menerapkan prinsip bimbingan dan konseling dapat melahirkan siswa-siswa yang bermental sehat.

2. Melihat mental siswa yang sedang menjelani sekolah polisi di Sekolah Polisi Negara Kepolisian Daerah Sumatera Utara, dengan penilaian mental siswa ditinjau dari masalah yang melakukan siswa terdapat larangan dan kewajiban. Apabila melanggar larangan maka mentalnya berkurang. Hal ini termasuk dalam aspek penialain akhir di ijazah yaitu: nilai akademik, nilai jasmani dan nilai mental kepribadian yang paling terpenting adalah nilai mental kepribadian. Mental 
INTIQAD: JURNAL AGAMA DAN PENDIDIKAN ISLAM

ISSN 1979-9950 (print) || ISSN 2598-0033 (online), http://jurnal.umsu.ac.id/index.php/intiqad

DOI: 10.30596/intiqad.v12i2.5586

Vol. 12, No. 2 (December 2020)

kepribdaian sudah tercermin pada saaat di mahasiswa, jadi apabila mental siswa bagus maka di dalam dunia pekerjaan akan bagus.

\section{Daftar Pustaka}

Abdurrahman. (2019). Konseling Islami, Medan: Perdana Publishing.

Akhyar Lubis, Saiful. (2011). Konseling

Islami dan Kesehatan Mental,

Bandung: Citapustaka Media Perintis.

Aqib, Zainal. (2001). Konseling kesehatan mental Jakarta: Yrama Widya.

Arikunto, Suharsimi. (1991). Prosedur Penelitian Suatu Pendekatan Praktek, Jakarta: Rieneka Cipta.

Azwar, Saifuddin. (2005). Metode Penelitian, Yogyakarta: Pustaka Pelajar.

Bogdan, R. dan Biklen, S.K. (1992). Qualitative Research for Education, Bostonn: Allyn and Bacon.

Bondan. (1998). Qualitatif Research In Education:An Introduction to Theory and Methode. Thrid Edition, Boston:Allyn and Baccon.
Bungin, Burhan. (2008). Analisis Data Penelitian Kualitatif, Jakarta: Rajawali Pers

Burhanuddin. (1999). Kesehatan Mental, Bandung: Pustaka Setia.

Depatermen Agama RI. 2005. Al-qur'an dan terjemahan Al-hikma, Bandung: $\quad \mathrm{CV}$ Penerbit Diponegoro.

Hasan, Iqbal. (2002). Metode Penelitian dan Aplikasinya, Jakarta: Ghia Indonesia.

Husain. Dkk. (1990). Metode Penelitian Sosial, Jakarta: Bumi Aksara.

Jaya, Yahya. (1994). Spritual Islam dan Menubuhkembangkan Kepribadian dan kesehatan mental. Jakarta: Ruhama.

Langgulung, Hasan. (2002). Peralihan Paradigma dalam Pendidikan islam dan sains social. Jakarta: Gaya Media Pratama.

Lexy, J. Moleong. (2016). Metodologi Penelitian Kualitatif. Bandung: Remaja Rosdakarya.

M. Luddin, Abu Bakar. (2009). Kinerja Kepala sekolah dalam kegiatan Bimbingan dan Konseing Medan: Perdana Mulya Sarana.

Mujib, Abdul dan Jusuf Mudzakir. (2002). Nuansa-nuansa psikolog 
ISSN 1979-9950 (print) || ISSN 2598-0033 (online), http://jurnal.umsu.ac.id/index.php/intiqad DOI: 10.30596/intiqad.v12i2.5586

Vol. 12, No. 2 (December 2020)

Islam. Jakarta: PT. RajaGrafindo Persada.

Narbuko, Cholid dan Abu Ahmadi. (2008). Metodologi Penelitian: Memberi Bekal Teoritis pada Mahasiswa tentang Metodologi Penelitian serta diharapkan dapat Melaksanakan Penelitian dengan Langkah-langkah yang Benar. Jakarta: Bumi Aksara.

Nasution, S. (2008). Metode Research. Jakarta: Bumi Aksara.

Nurihsan, Achmad Juntika. (2009). Bimbingan dan Konseling Berbagai Latar Kehidupan. Bandung: PT. Refika Aditama.

Peraturan bersama Menteri Pendidikan Nasional dan Kepala Badan Kepegawaian Negara Nomor 03/V/PB/2010 dan Nomor 14 Tahun 2010.

Pohan, Andana, dkk. (2017). Wawasan

Dasar Bimbingan Konseling, Medan: Perdana Publishing.

Prayitno dan Erman Amti. (2008). Dasar-dasar Bimbingan dan Konseling. Jakarta: PT. Rineka Cipta.

Prayitno. (1999). Seri Pemandu Pelaksanaan BK Disekolah Buku
III Pelayanan BK (SMU). Jakarta: PT. Ikrar Mandiri Abbadi.

Prayitno. (2017). Konseling Profesional Yang Berhasil. Jakarta: Rajawali Pers.

Qisthiyansah, Lutfhi. (2014). Pengaruh Pemberian Usaha Kesehatan Jiwa Sekolah Terhadap Tingkat Depresi Siswa SMP Kelas XI Dalam Menghadapi Ujian Nasional Di Kecamatan Gamping. Program Studi Ilmu Keperawatan Sekolah Tinggi Ilmu Kesehatan Aisyiyah Yogyakarta: Vol.1.

Rafi'udin. (2001). Hadits-Hadits Pilihan. Jakarta: Bina Utama Publishing.

Rahmulyani. Lembar Kerja Teori Layanan Bimbingan Kelompok, Medan: Jurusan Bimbingan dan Konseling Fakultas Ilmu Pendidikan UNIMED.

Ramayulis dan Mulyadi. (2016). Bimbingan dan Konseling Islam di Madrasah dan Sekolah. Jakarta: Kalam Mulia.

Rustam. (2006). Rancangan Penelitian Sosial Keagamaan. Medan: Pusat Penelitian IAIN SU. 
INTIQAD: JURNAL AGAMA DAN PENDIDIKAN ISLAM

ISSN 1979-9950 (print) || ISSN 2598-0033 (online), http://jurnal.umsu.ac.id/index.php/intiqad DOI: 10.30596/intiqad.v12i2.5586

Vol. 12, No. 2 (December 2020)
Salim dan Syahrum.(2007). Penelitian

Kualitatif. Bandung: Citapustaka Media.

Shihab, Quraish. (2002). Tafsir alMisbah: Pesan, Kesan dan Keserasian al-Quran Jakarta: Lentera Hati.

Sugiyono. (2009). Metode Penelitian

Pendidikan:

Pendekatan

Kuantitatif, Kualitatif, dan $R \& D$. Bandumg: Alfabeta

Sukmadinata, Nana Syaodih. (2007).

Metode Penelitian Pendidikan.

Bandung: PT. Remaja Rosdakarya.

Sururin. (2004). Ilmu Jiwa Agama.

Jakarta: PT. Raja Grafindo

Persada.

Suryadi. (2013). Strategi Pembelajaran

Pendidikan Karakter. Bandung:

Remaja Rosdakarya.

Tohirin. (2013). Bimbingan dan

Konseling di Sekolah dan Madrasah. Jakarta : Rajawali Pers.

Tohirin. (2007). Bimbingan dan Konseling di Sekolah Madrasah. Jakarta: PT. Raja Grafindo Persada.

Tumanggor, Rusmin. (2002). Ilmu Jiwa Agama. Depok: Ulinnuha.
Undang-undang No. 20 Tahun 2003 tentang Sistem Pendidikan Nasional.

Winkel, W.S dan Sri Hastuti. (2012). Bimbingan dan Konseling di Institusi Pendidikan. Yogyakarta: Media Abadi.

Yusuf, Syamsu dan A. Juntika Nurihsan. (2011). Landasan Bimbingan Dan Konseling. Bandung: PT. Remaja Rosdakarya. 